\title{
Uji Aktivitas Antihiperlipidemia Ekstrak Etanol Daun Notika (Arcboldiodendron calosericeum Kobuski) Terhadap Kadar Kolesterol Total Tikus (Rattus norvegicus) Jantan Galur Wistar
}

\author{
Nuralifah ${ }^{*}$, Wahyuni, Parawansah, Ulan Dwi Shintia \\ 1,2,3,4 Jurusan Farmasi, Fakultas Farmasi, Universitas Halu Oleo, \\ Jl. HEA Mokodompit, Kampus Hijau Bumi Tridharma Anduonohu Kendari 93232, Indonesia \\ *Penulis Korespondensi. Email: nuralifahapt11@gmail.com
}

\section{ABSTRAK}

Hiperlipidemia adalah peningkatan kadar lemak dalam darah karena konsumsi lemak secara berlebihan, sehingga asupan dan perombakan lemak tidak seimbang. Tumbuhan Notika merupakan tanaman yang memiliki kandungan senyawa metabolit sekunder berupa flavonoid, tannin, saponin dan triterpenoid yang merupakan senyawa antioksidan yang diduga mempunyai efek menurunkan lipid darah. Penelitian ini bertujuan untuk mengetahui efek ekstrak etanol daun Notika terhadap penurunan kadar kolesterol total pada tikus yang diinduksi kuning telur dan propiltiourasil (PTU). Penelitian ini bersifat eksperimental yang dilakukan pada 6 kelompok, yaitu 4 kelompok yang diberi ekstrak etanol daun Notika dengan dosis $50 \mathrm{mg} / \mathrm{kg} \mathrm{BB}, 100 \mathrm{mg} / \mathrm{kg} \mathrm{BB}, 200 \mathrm{mg} / \mathrm{kg} \mathrm{BB}$, dan $300 \mathrm{mg} / \mathrm{kg} \mathrm{BB}$, satu kelompok diberi Na CMC 0,5\% sebagai kontrol negatif, dan satu kelompok diberi simvastatin $10 \mathrm{mg}$ sebagai kontrol positif. Hasil penelitian menunjukkan bahwa ekstrak etanol daun Notika signifikan menurunkan kadar kolesterol total tikus dengan nilai signifikan $<0,05$, dan pada dosis 300 $\mathrm{mg} / \mathrm{kgBB}$ efektif menurunkan kadar kolesterol total tikus.

Kata Kunci:

Notika, Archboldiodendron calosericeum Kobuski, Kolesterol total

\begin{tabular}{ccc}
\hline Diterima: & Disetujui: & Online: \\
$28-09-19$ & $10-11-19$ & $10-12-19$ \\
\hline
\end{tabular}

\section{ABSTRACT}

Hyperlipidemia is an increase of lipid due to excessive fat consumption, that the intake and alteration of lipid is not balanced. Notika are plants that contain secondary metabolites in the form of flavonoids, tannins, saponins and triterpenoids which are antioxidant compounds that are thought to have the effect of reducing blood lipids. This study aims to determine the effect of ethanol extract of leaves of Notika on decreasing total cholesterol levels in rats induced by egg and propylthiouracil (PTU). This research was experimental in 6 groups, namely 4 groups given ethanol extract of leaves of Notika at a dose of 50 $\mathrm{mg} / \mathrm{kgBB}, 100 \mathrm{mg} / \mathrm{kgBB}, 200 \mathrm{mg} / \mathrm{kgBB}$, and $300 \mathrm{mg} / \mathrm{kgBB}$, one group was given $\mathrm{Na} \mathrm{CMC} 0.5 \%$ as a negative control, and one group was given simvastatin $10 \mathrm{mg}$ as a positive control. The results showed that the ethanol extract of the leaves of Notika significantly reduced the total cholesterol level of rats with a significant value $<0.05$ and $300 \mathrm{mg} / \mathrm{kgBB}$ is an effective dose to reduce total cholesterol level.

\section{Keywords:}

Notika, Archboldiodendron calosericeum Kobuski, total cholesterol

$\begin{array}{ccc}\text { Received: } & \text { Accepted: } & \text { Online: } \\ \text { 19-09-28 } & 19-11-10 & 19-12-10\end{array}$




\section{Pendahuluan}

Kolesterol merupakan salah satu penyebab penyakit kardiovaskuler yang merupakan penyakit mematikan dan telah menjadi masalah serius di negara maju maupun berkembang. Organisasi Kesehatan Sedunia (WHO) dan Organisasi Federasi Jantung Sedunia (World Heart Federation) memprediksi bahwa penyakit jantung akan menjadi penyebab utama kematian di negara-negara Asia [23]. Penyakit jantung koroner terutama disebabkan oleh kelainan miokardium akibat insufisiensi aliran darah koroner karena aterosklerosis. Aterosklerosis merupakan penyakit degeneratif arteri besar dan menengah yang ditandai dengan penimbunan lipid dan fibrosis [1]. Etiologi aterosklerosis adalah multifaktorial tetapi ada berbagai keadaan yang erat kaitannya dengan aterosklerosis yaitu: hiperlipidemia, hipertensi, kebiasaan merokok, diabetes mellitus, olahraga, keturunan, dan stress [2]. Hiperlipidemia merupakan suatu keadaan tingginya konsentrasi lipid yang ditandai dengan meningkatnya konsentrasi trigliserida, LDL (low density lipoprotein), dan kolesterol darah melebihi batas normal (pada manusia > $200 \mathrm{mg} / \mathrm{dl}$ ). Keadaan ini dapat ditimbulkan karena meningkatnya peroksidasi lipid yang disebabkan oleh radikal bebas di dalam tubuh, seperti organ hati [7].

Menurut hasil Riskesdas tahun 2013, terdapat 35,9\% penduduk di Indonesia yang memiliki gangguan kolesterol total, 15,9\% memiliki kadar LDL tinggi, 11,9\% memiliki kadar trigliserida tinggi, dan 22,9\% memiliki kadar HDL rendah $(<40 \mathrm{mg} / \mathrm{dl})$ [18]. Kondisi hiperlipidemia ini dapat diturunkan dengan menggunakan obat-obatan antara lain golongan asam fibrat, resin, penghambat HMG CoA reduktase (statin), dan asam nikotinat (niasin) [7]. Selain penggunaan obat untuk mengatasi problem kolesterol yang tinggi di darah, masyarakat juga telah mulai menggunakan bahan-bahan alami untuk menurunkan kadar kolestrol darah [17]. Pengetahuan tentang tanaman berkhasiat obat berdasarkan pada pengalaman dan keterampilan yang secara turun-temurun telah diwariskan dari satu generasi ke generasi berikutnya [3]. Indonesia sendiri memiliki beragam jenis tanaman obat salah satunya tumbuhan Notika.

Tumbuhan Notika merupakan salah satu tanaman yang biasa digunakan sebagai obat tradisional masyarakat Papua. Daun Notika diketahui mengandung senyawa metabolit sekunder flavonoid, tannin, saponin dan triterpenoid[21]. Senyawa metabolit tersebut bersifat sebagai antioksidan yang berperan terhadap mekanisme perbaikan profil lipid [27]. Flavonoid mengurangi sintesis kolesterol dengan cara menghambat aktivitas enzim acyl-CoA cholesterol acyl transferase (ACAT) pada sel HepG2 yang berperan dalam penurunan esterifikasi kolesterol pada usus dan hati, serta menghambat aktivitas enzim 3-hidroksi-3-metil-glutaril-CoA yang menyebabkan penghambatan sintesis kolesterol. Saponin dapat berikatan dengan asam empedu dan kolesterol (dari makanan) membentuk misel yang juga tidak dapat diserap oleh usus. Sedangkan tannin di dalam tubuh akan berikatan dengan protein tubuh dan akan melapisi dinding usus, sehingga penyerapan lemak terhambat [4].

\section{Metode}

\subsection{Bahan}

Aquadest, alkohol 70\%, daun Notika (Archboldiodendron calossericeum (Kobuski)), etanol $96 \%, \mathrm{FeCl}_{3}, \mathrm{H}_{2} \mathrm{SO}_{4}, \mathrm{HCl}$, kertas saring, kloroform, kuning telur puyuh, tikus putih (Rattus norvegicus) jantan, NaCMC 0,5\%, propiltiourasil (PTU), pereaksi Dragendorff, pereaksi Liebeman-Buchard, serbuk magnesium, simvastatin $10 \mathrm{mg}$. 


\section{2..2 Ekstraksi}

Metode ekstraksi yang digunakan yaitu metode maserasi. Serbuk daun Notika sebanyak $500 \mathrm{~g}$ dimasukan ke dalam wadah tertutup dan direndam dengan menggunakan pelarut etanol 96\% selama $3 \times 24$ jam pada suhu kamar. Setiap $1 \times 24$ jam dilakukan penyaringan dan penggantian pelarut baru sehingga diperoleh filtrat I, II, dan III. Filtrat dikumpulkan dan dipekatkan dengan penguapan berputar menggunakan rotary vacum evaporator pada suhu $50^{\circ} \mathrm{C}$ hingga diperoleh ekstrak kental.

\subsection{Skrining Fitokimia}

a. Uji alkaloid

Ekstrak dilarutkan dengan $5 \mathrm{~mL}$ HCL larutan yang didapat kemudian dimasukkan dalam tabung reaksi. Tabung ditambahkan pereaksi Dragendroff sebanyak 3 tetes. Terbentuknya endapan jingga pada tabung menunjukkan adanya alkaloid [19].

b. Uji flavonoid

Ekstrak kemudian ditambahkan etanol. Kedalam larutan ditambahkan serbuk magnesium dan ditambahkan HCL. Terbentuk larutan berwarna merah jingga menunjukkan adanya flavonoid.

c. Uji terpenoid

Uji terpenoid dilakukan dengan reaksi Lieberman - Burchard. Terbentuknya larutan hijau biru menunjukkan adanya terpenoid [24].

d. Uji saponin

Ekstrak ditambahkan dengan $10 \mathrm{~mL}$ air panas kemudian didinginkan, dikocok kuat selama 10 detik. Terbentuk buih yang mantap selama tidak kurang 10 menit.

e. Uji tannin

Ekstrak ditambahkan dengan $1 \mathrm{~mL}$ larutan Fe (III) klorida 1\%. Jika terbentuk warna biru tua, biru kehitaman atau hitam kehijauan menunjukkan adanya senyawa tannin [24].

\subsection{Uji Aktivitas Antihiperlipidemia}

a. Pengelompokkan hewan uji

Tikus dibagi menjadi 6 kelompok, tiap kelompok beranggotakan 3 ekor tikus. Kelompok 1 yaitu kelompok kontrol negatif. Kelompok 2 yaitu kelompok kontrol positif yang diberi simvastatin. Kelompok 3, 4, 5 dan 6 adalah kelompok uji yang diberikan suspensi ekstrak dengan dosis masing-masing $50 \mathrm{mg} / \mathrm{kgBB}$, $100 \mathrm{mg} / \mathrm{kgBB}, 200 \mathrm{mg} / \mathrm{kgBB}$ dan $300 \mathrm{mg} / \mathrm{kgBB}$.

b. Pembuatan Makanan Diet Tinggi Lemak (MDTL)

Makanan diet tinggi lemak dibuat dengan mencampurkan $10 \mathrm{~mL}$ kuning telur puyuh dan $1,8 \mathrm{mg} / \mathrm{kgBB}$ propiltiourasil (PTU).

c. Pengujian Antihiperlipidemia

a) Kadar kolesterol tikus diukur untuk memperoleh kadar kolesterol awal

b) Tikus diberi pakan tambahan berkadar kolesterol tinggi selama 14 hari untuk mendapatkan kondisi hiperkolesterolemi pada tikus.

c) Kadar kolesterol diukur kembali untuk mengetahui peningkatan kadar kolesterol. 
d) Setelah itu dilakukan randomisasi untuk mengelompokkan 18 ekor tikus menjadi kelompok kontrol negatif (K-), kelompok kontrol positif $(\mathrm{K}+)$, dan empat kelompok perlakuan $(\mathrm{P})$.

e) Selanjutnya selama 14 hari setiap kelompok mendapat perlakuan sebagai berikut:

i. Kontrol negatif (K1) : tikus diberi Na CMC 0,5\%

ii. Kontrol positif (K2) : diberi Simvastatin dosis $10 \mathrm{mg} / \mathrm{kgBB}$

iii. Kelompok uji 1 : diberi ekstrak etanol daun Notika dengan dosis 50 $\mathrm{mg} / \mathrm{kgBB}$

iv. Kelompok uji 2: diberi ekstrak etanol daun Notika dengan dosis 100 $\mathrm{mg} / \mathrm{kgBB}$

v. Kelompok uji 3 : diberi ekstrak etanol daun Notika dengan dosis 200 $\mathrm{mg} / \mathrm{kgBB}$

vi. Kelompok uji 4 : diberi ekstrak etanol daun Notika dengan dosis 300 $\mathrm{mg} / \mathrm{kgBB}$

f) Setelah hari ke 15 dilakukan pengujian kadar kolesterol total

\section{Hasil dan Pembahasan}

\subsection{Ekstraksi}

Ekstraksi merupakan proses pemisahan bahan dari campurannya dengan menggunakan pelarut yang sesuai. Ekstraksi daun Notika dilakukan dengan metode maserasi dengan menggunakan etanol 96\% sebagai pelarut. Metode maserasi digunakan karena cara pengerjaannya sederhana dan alat yang dibutuhkan mudah untuk diperoleh. Penggunaan Etanol dipilih berdasarkan metode yang distandarisasi yang menjelaskan bahwa untuk ekstraksi suatu bahan yang akan digunakan sebagai obat harus menggunakan etanol sebagai pelarutnya. Selain itu etanol mudah menguap, murah, mudah didapat dan cukup aman. Hasil maserasi berupa maserat dikumpulkan dan kemudian dipekatkan dengan menggunakan vacuum rotary evaporator pada suhu $50^{\circ} \mathrm{C}$. Hasil ekstraksi dari simplisia daun Notika diperoleh ektrak kental berwarna hijau pekat sebanyak 158,36 gram dengan rendemen ekstrak 7,918\%.

\subsection{Skrining Fitokimia}

Skrining fitokimia dalam penelitian ini menggunakan metode analisis kualitatif melalui reaksi perubahan warna atau reaksi pengendapan setelah penambahan reaksi tertentu yang bertujuan untuk mengetahui senyawa yang terkandung di dalam ekstrak etanol daun Notika sehingga dapat dijadikan dasar dalam memperkirakan senyawa golongan yang berkhasiat pada penelitian ini. Hasil metode pengendapan/pewarnaan dapat dilihat pada Tabel 1.

Pada pengujian alkaloid akan terjadi reaksi pengendapan karena adanya penggantian ligan. Atom nitrogen yang mempunyai pasangan elektron bebas pada alkaloid mengganti ion iod dalam pereaksi Dragendorff. Hal ini mengakibatkan terbentuknya endapan jingga pada penambahan pereaksi Dragendorff karena nitrogen digunakan untuk membentuk ikatan kovalen koordinat dengan $\mathrm{K}^{+}$yang merupakan ion logam. Pada uji alkaloid dengan penambahan pereaksi Dragendorff menghasilkan warna hitam sehingga ekstrak daun Notika negatif mengandung alkaloid.

Pengujian terpenoid didasarkan pada kemampuan senyawa untuk membentuk warna dengan $\mathrm{H}_{2} \mathrm{SO}$ pekat dalam pelarut asam asetat anhidrat. Uji terpenoid ekstrak 
daun Notika menghasilkan perubahan warna menjadi kecoklatan yang menunjukkan ekstrak daun Notika positif mengandung terpenoid. Pada uji flavonoid ekstrak daun Notika ditambahkan magnesium dan $\mathrm{HCl}$ menunjukkan terbentuknya warna jingga sehingga daun Notika dikatakan positif mengandung flavonoid. Magnesium dan $\mathrm{HCl}$ pekat pada uji ini berfungsi untuk mereduksi inti benzopiron yang terdapat pada struktur flavonoid sehingga terbentuk perubahan warna menjadi merah atau jingga [23].

Saponin merupakan senyawa yang mempunyai gugus hidrofilik dan hidrofob. Pada saat digojok gugus hidrofil akan berikatan dengan air sedangkan gugus hidrofob akan berikatan dengan udara sehingga membentuk buih. Pada uji saponin daun Notika yang ditambahkan air dan dikocok menghasilkan buih sehingga daun Notika dikatan positif mengandung saponin. Daun Notika positif mengandung senyawa tannin karena pada saat di tambahkan pereaksi terbentuk warna hijau kehitaman. Perubahan warna ini terjadi ketika penambahan $\mathrm{FeCl}_{3}$ yang bereaksi dengan salah satu gugus hidroksil yang ada pada senyawa tannin[23].

\subsection{Pengujian Kolesterol Total}

\section{a. Pemberian makanan diet tinggi lemak (MDTL)}

Pemberian makanan tinggi lemak ini bertujuan untuk meningkatkan kadar kolesterol total plasma tikus. Makanan diet tinggi lemak yang diberikan terdiri dari kuning telur $10 \mathrm{~mL} / \mathrm{kgBB}$ dan PTU (propiltiourasil) 1,8 mg/200 kgBB [22]. PTU merupakan zat antitiroid yang dapat merusak kelenjar tiroid sehingga menghambat pembentukan hormon tiroid. Hormon tiroid dapat menurunkan kadar kolesterol dalam darah dengan cara meningkatkan pembentukkan LDL di hati yang mengakibatkan peningkatan pengeluaran kolesterol dari sirkulasi. Kekurangan hormon tiroid mengakibatkan katabolisme kolesterol menurun, sehingga terjadi peningkatan kolesterol dalam darah. Setelah pemberian makan diet tinggi lemak, tikus kemudian diberikan terapi ekstrak etanol daun Notika dengan dosis $50 \mathrm{mg}, 100 \mathrm{mg}, 200 \mathrm{mg}$ dan 300 $\mathrm{mg}$ serta simvastatin dengan dosis $10 \mathrm{mg}$ sebagai pembanding.

\section{b. Pengukuran kadar kolesterol total}

Pengukuran darah dilakukan sebanyak tiga kali dengan selang waktu yang berbeda. Pengukuran pertama dilakukan setelah aklitimasi sebagai data kolesterol awal $\left(\mathrm{H}_{0}\right)$. Pengukuran darah kedua dilakukan setelah 15 hari pemberian makanan diet tinggi lemak $\left(\mathrm{H}_{15}\right)$. Pengambilan darah ke tiga dilakukan pada hari ke 30 setelah pemberian ekstrak daun Notika $\left(\mathrm{H}_{30}\right)$. Kemudian dihitung rata-rata kadar kolesterol total pada setiap kelompok perlakuan. Grafik rata-rata hasil pengukuran kadar kolesterol total tikus dapat dilihat pad gambar 1.

Berdasarkan gambar 1. dapat di lihat bahwa pada $\mathrm{H}_{15}$ terjadi peningkatan kadar kolesterol total pada setiap kelompok perlakuan. Kadar kolesterol setelah pemberian makan diet tinggi lemak mengalami peningkatan yang disebabkan karena komponen emulsi berupa kuning telur puyuh yang mengandung kolesterol sebesar 2138,17 $\mathrm{mg} / 100 \mathrm{~g}$, serta PTU dengan mekanisme kerjanya sebagai antitiroid yang menurunkan katabolisme kolesterol sehingga terjadi peningkatan kolesterol. Berdasarkan penelitian yang dilakukan Allo dkk., 2014 pemberian PTU selama 14 hari dapat meningkatkan kadar kolesterol total tikus.

Selisih rata-rata kadar kolesterol total $\mathrm{H}_{30}$ dan $\mathrm{H}_{15}$ dapat dilihat pada tabel 2 .

Berdasarkan data Tabel 2 kelompok kontrol negatif menunjukkan peningkatan rerata kadar kolesterol total tikus yaitu $33,67 \mathrm{mg} / \mathrm{dl}$. Hal ini menunjukkan pemberian $\mathrm{Na}$ CMC tidak mempengaruhi atau mengurangi kadar kolesterol total pada tikus. Kelompok kontrol positif menunjukkan penurunan kadar kolesterol total tikus yaitu 
$84,67 \mathrm{mg} /$ dl. Kelompok ekstrak etanol daun Notika dengan dosis 50 mg menunjukkan peningkatan kolesterol total tikus sebesar $4 \mathrm{mg} / \mathrm{dl}$ ini disebabkan karena dosis yang diberikan terlalu kecil sehingga tidak memberikan efek antihierlipidemia. Kelompok ekstrak etanol daun Notika dengan dosis $100 \mathrm{mg}$ menunjukkan penurunan kadar kolesterol total tikus yaitu 48,43 mg/dl. Kelompok ekstrak etanol daun Notika dengan dosis $200 \mathrm{mg}$ menunjukkan penurunan kadar kolesterol total tikus yaitu 68,33 mg/ dl. Kelompok ekstrak etanol daun Notika dengan dosis $300 \mathrm{mg}$ menunjukkan penurunan kadar kolesterol total tikus yaitu 85,33 mg/dl. Hasil pengukuran kadar kolesterol total pada kelompok ekstrak etanol daun Notika dosis 100 mg/kgBB, 200 mg/kgBB dan 300 $\mathrm{mg} / \mathrm{kgBB}$ menunjukkan adanya pengaruh dalam menurunkan kadar kolesterol total tikus.

Adanya kontrol negatif dan positif dimaksudkan sebagai pembanding untuk mengetahui adanya pengaruh terhadap hewan percobaan. Kontrol negatif yang digunakan adalah larutan Na-CMC yang sekaligus sebagai suspending agent. Sedangkan kontrol positif yang digunakan adalah simvastatin dengan dosis $10 \mathrm{mg} /$ hari sebagai pembanding karena mampu menurunkan kadar kolesterol total sebanyak $20 \%$ dan menurunkan resiko penyakit pembuluh darah sebanyak $24 \%$. Simvastatin yang digunakan sebagai pembanding juga memiliki mekanisme antikolesterol dengan menghambat secara kompetitif enzim HMG-CoA reduktase yang mempunyai fungsi sebagai katalis dalam pembentukan kolesterol [26].

Berdasarkan hasil skrining fitokimia daun Notika mengandung senyawa flavonoid, tanin, dan saponin. Senyawa yang diduga memiliki aktivitas anti hipoliidemik adalah senyawa flavonoid. Flavonoid bekerja sebagai inhibitor enzim HMG-CoA reduktase sehingga sintesis kolesterol menurun. Pada saat kolesterol ditranspor dari usus ke hati, maka HMG-CoA reduktase yang berrtugas mengubah asetil-koA menjadi mevalonat dalam sintesis kolesterol akan terhambat sehingga produk sintesis kolesterol oleh hati akan berkurang.

Senyawa lain yang diduga berperan dalam penurunan kadar kolesterol total tikus yaitu saponin. Saponin bekerja dengan cara mengendapkan kolesterol dan ikut dalam sirkulasi enterohepatik asam empedu yang membuat penyerapan kolesterol di usus terganggu. Tannin yang terkandung dalam ekstrak etanol daun Notika juga kemungkinan memiliki efek dalam menurunkan kadar kolesterol melalui aktivitasnya sebagai antioksidan. Tannin bekerja dengan cara mengikat lipid di saluran pencernaan sehingga mengganggu absorbsi lipid di dalam usus.

Hasil uji one way ANOVA pada pengukuran kadar kolesterol total tikus memiliki nilai signifikansi $(\alpha<0,05)$ yang berarti terdapat perbedaan yang signifikan. Selanjutnya dilakukan pengujian lanjutan yaitu uji LSD (Least Significant Difference) yang dapat dilihat pada tabel 3. Hasil uji LSD juga menunjukkan bahwa kelompok kontrol positif (+) dengan kelompok DP50 diperoleh $p$ value 0,002 < 0,05 yang artinya bermakna dan terdapat perbedaan yang signifikan. Sedangkan pada kelompok kontrol positif $(+)$ dengan DP100 diperoleh $p$ value sebesar 0,121 > 0,05, kelompok kontrol positif $(+)$ dengan DP200 diperoleh $p$ value sebesar 0,768 > 0,05 dan kelompok kontrol positif $(+)$ dengan DP300 diperoleh $p$ value sebesar 0,687 > 0,05 yang artinya tidak terdapat perbedaan yang bermakna antara ketiga kelompok perlakuan dengan kontrol positif. Dengan demikian ekstrak daun Notika yang diberikan selama 15 hari mampu menurunkan kadar kolesterol total tikus yang sebanding dengan simvastatin. 
3.3. Tabel dan Gambar

Tabel 1 : Hasil Skrining Fitokimia

\begin{tabular}{|c|c|c|c|c|}
\hline $\begin{array}{l}\text { Metabolit } \\
\text { Sekunder }\end{array}$ & Pengujian & Gambar & $\begin{array}{l}\text { Warna yang } \\
\text { Terbentuk }\end{array}$ & $+/-$ \\
\hline Alkaloid & $\begin{array}{l}\text { Ekstrak ditambahkan } \\
\text { pereaksi Dragendorff }\end{array}$ & & Hitam & - \\
\hline Terpenoid & $\begin{array}{c}\text { Ekstrak ditambahkan } 0,5 \\
\text { ml asam asetat anhidrat } \\
\text { dan } 2 \mathrm{~mL} \text { asam sulfat pekat }\end{array}$ & & Coklat & + \\
\hline Flavonoid & $\begin{array}{c}\text { Ekstrak ditambahkan } 0,5 \\
\mathrm{HCl} \text { pekat dan serbuk } \\
\text { magnesium }\end{array}$ & & $\begin{array}{l}\text { Endapan } \\
\text { coklat muda }\end{array}$ & + \\
\hline Saponin & $\begin{array}{c}\text { Ekstrak ditambahkan air } \\
\text { lalu dikocok selama } 10 \\
\text { detik }\end{array}$ & & Busa & + \\
\hline Tanin & $\begin{array}{c}\text { Ekstrak ditambahkan } 1 \mathrm{~mL} \\
\text { larutan } \mathrm{FeCl}_{3} 1 \%\end{array}$ & & $\begin{array}{c}\text { Hijau } \\
\text { kehitaman }\end{array}$ & + \\
\hline
\end{tabular}

\section{Rata-rata kadar kolesterol total tikus}

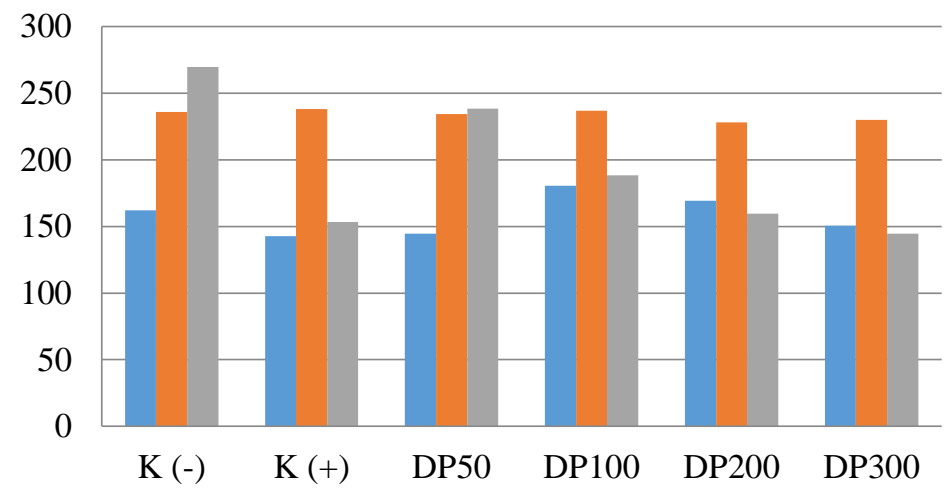

- Rata-rata Kadar Kolesterol Total Tikus H0

- Rata-rata Kadar Kolesterol Total Tikus H15

Rata-rata Kadar Kolesterol Total Tikus H-30

Gambar 1. Grafik rata-rata kadar kolesterol total tikus 
Tabel 2. selisih rerata kadar kolesterol total tikus

\begin{tabular}{llll}
\hline \multirow{2}{*}{ Kelompok } & \multicolumn{2}{l}{ Rerata kadar kolesterol total $(\mathbf{m g} / \mathbf{d l})$} & $\begin{array}{l}\text { Selisih kadar } \\
\text { total } \mathbf{( m g / d )}\end{array}$ \\
\cline { 2 - 4 } & $\mathrm{H}_{15}$ & $\mathrm{H}_{30}$ & $-33,67$ \\
\hline K(-) & 236,00 & 269,67 & 84,67 \\
\hline K(+) & 238,00 & 153,33 & -4 \\
\hline DP50 & 234,33 & 238,33 & 48,34 \\
\hline DP100 & 236,67 & 188,33 & 68,33 \\
\hline DP200 & 228,00 & 159,67 & 85,33 \\
\hline DP300 & 230,00 & 144,67 & \\
\hline
\end{tabular}

Tabel 3. Hasil Uji LSD (Least Significant Difference)

\begin{tabular}{ccccccc}
\hline \multirow{2}{*}{ Kelompok } & $\mathbf{7}$ Nilai P value kelompok \\
\cline { 2 - 7 } & $\mathbf{K}(-)$ & $\mathbf{K}(+)$ & $\mathbf{D P 5 0}$ & $\mathbf{D P 1 0 0}$ & $\mathbf{D P 2 0 0}$ & $\mathbf{D P 3 0 0}$ \\
\hline K (-) & - & $0,000^{*}$ & 0,161 & $0,002^{*}$ & $0,000^{*}$ & $0,000^{*}$ \\
\hline $\mathbf{K}(+)$ & $0,000^{*}$ & - & $0,002^{*}$ & 0,121 & 0,768 & 0,687 \\
\hline DP50 & 0,161 & $0,002^{*}$ & - & $0,035^{*}$ & $0,003^{*}$ & $0,001^{*}$ \\
\hline DP100 & $0,002^{*}$ & 0,121 & $0,035^{*}$ & - & 0,197 & 0,059 \\
\hline DP200 & $0,000^{*}$ & 0,768 & $0,003^{*}$ & 0,197 & - & 0,488 \\
\hline DP300 & $0,000^{*}$ & 0,687 & $0,001^{*}$ & 0,059 & 0,488 & - \\
\hline
\end{tabular}

$*=p<0,05:$ signifikan

Keterangan:

$\mathrm{K}(-) \quad$ : kelompok kontrol negatif yang di beri $\mathrm{Na} \mathrm{CMC}$

$\mathrm{K}(+) \quad$ : kelompok kontrol positif yang diberi simvastatin

DP50 : kelompok perlakuan yang diberi ekstrak daun Notika dosis $50 \mathrm{mg}$

DP100 : kelompok perlakuan yang diberi ekstrak daun Notika dosis $100 \mathrm{mg}$

DP200 : kelompok perlakuan yang diberi ekstrak daun Notika dosis $200 \mathrm{mg}$

4. Kesimpulan

Pemberian ekstrak etanol daun Notika kepada tikus jantan galur Wistar menunjukkan adanya aktivitas Antihiperlipidemia terhadap penurunan kadar kolesterol total. Dosis ekstrak etanol daun Notika yang efektif dalam menurunkan kolesterol total yaitu dosis $300 \mathrm{mg}$, dosis tersebut dapat menurunkan kolesterol total sebesar $85,33 \mathrm{mg} / \mathrm{dl}$. Adapun saran peneliti agar dilakukan penelitian lebih lanjut tentang efek antihiperlipidemia ekstrak etanol daun Notika terhadap profil lipid tikus yang mencakup kadar trigliserida, LDL (Low Density Lipoprotein), HDL (High Density Lipoprotein) dan VLDL (Very Low Density Lipoprotein).

\section{Referensi}

(1) Underwood JCE. Aterosklerosis.Didalam: Sarjadi,editor. Patologi Umum dan Sistemik Edisi 2. Jakarta:EGC,1999:326-29.

(2) Handoko T, Suyatna F.D. Hipolipidemik. Di dalam: Ganiswara S G, Setiabudy R, Suyatna F D, Purwantyastuti, Nafrialdi, editor. Farmakologi dan Terapi edisi 5. Jakarta. Bagian Farmakologi FKUI, 2007: 373-388. 
(3) Allo, I.G., Pemsi, M.W., dan Henoch, A., 2013, Uji Efek Ekstrak Etanol Daun Jambu Biji (Psidium guajava L) Terhadap Kadar Kolesterol Total Tikus Wistar (Rattus norvegicus), Jurnal e-Biomedik, 1(1)

(4) Arief, M.I., Riky N., Indra T.B., Muhammad B.H., 2012, Potensi Bunga Karamunting (Melastoma malabathricum L.) Terhadap Kadar Kolesterol Total Dan Trigliserida Pada Tikus Putih Jantan Hiperlipidemia Yang Diinduksi Propiltiourasil, Prestasi,1 (2)

(5) Azizah, B., dan Nina S., 2013. Standarisasi Parameter Non Spesifik dan Perbandingan Kadar Kurkumin Ekstrak Etanol dan Ekstrak Terpurifikasi Rimpang Kunyit Kunyit, Jurnal Ilmiah Kefarmasian, 3 (1)

(6) Brass, L.J., 1933, British Papua New Guinea: Central Division, Mt. Tafa, landslip regrowths, 2400 m, Also in Herbarium, Journal Of The Arnold Arboretum 21(2) :143. 1940.

(7) Chairunnisa, N.H., 2015, Efectivity of Roselle Extract (Hibiscus sabdariffa L.) as Treatment For Hyperlipidemia, Jurnal Majority, 4(4)

(8) Departemen Kesehatan RI, 1985, Cara Pembuatan Simplisia, Direktorat Jendral PO, Jakarta.

(9) Departemen Kesesehatan RI, 1995. Materia Medika, Jilid VI, Diktorat Jenderal POM, Jakarta.

(10) Depertemen Kesehatan RI, 2000. Parameter Standar Umum Ekstrak Tumbuhan Obat, Diktorat Jendral POM, Jakarta.

(11) Direktorat Jendral POM, 2008, Farmakope Herbal Indonesia Edisi 1, Dep Kesehat RI: Jakarta.

(12) Dipiro, J.T., Barbara, G.W, Terry, L.S., dan Cecilly, V.D., 2012, Pharmacotherapy Handbook, The Mc Graw-Hill Companies, New York

(13) Erwinanto, 2013, Pedoman Tatalaksana Dislipidemia, Edisi 1, PERKI

(14) Global Biodiversity Information Facility, 2017, Arcboldiodendron calosericeum subsp. Merillianum (Kobuski) Barker http://www.tropicos.org/Name/50 233818. Published In: Journal of the Arnold Arboretum 21 (2) : 143.1940

(15) Global Biodiversity Information Facility Backbone Taxonomy, 2005, Arcboldiodendron calosericeum subsp. Merillianum (Kobuski) Barker http://www.gbif.org/species/7313963. Published In: Journal of the Arnold Arboretum 21 (2) : 143.1940

(16) Harborne, J.B., 2006, Metode Fitokimia: Penuntun Cara Modern Menganalisis Tumbuhan, ITB Press, Bandung

(17) Harjana, T., 2011, Kajian Tentang Potensi Bahan-Bahan Alami Untuk Menurunkan Kadar Koleterol Darah, Prosiding Seminar Nasional Penelitian

(18) Hayudanti, D., Inggita, K., dan Kanthi, P.T., 2016, Pengaruh Pemberian Jus Jambu Biji Merah (Psidium guajava) dan Jeruk Siam (Citrus nobilis) terhadap Kadar High Density Lipoprotein (HDL) pada Pasien Dislipidemia, Indonesian Journal of Human Nurition, 3(1)

(19) Jones, W.P. dan Kinghorn, A.D., 2006, Extraction of plant secondary metabolites, In:L Sarker, S.D., Latif, Z. dan Gray, A.I,. Natural Products Isolation, $2^{\text {nd }}$ Ed. New Jersey Humana Press.

(20) Mukhriani, 2014, Ekstraksi, Pemisahan Senyawa, dan Identifikasi Senyawa Aktif, Jurnal Kesehatan, 7 (2)

(21) Nuralifah Nuralifah, Asriullah Jabbar, Parawansah Parawansah, Ria Agus Iko., (2018). Uji Toksisitas Akut Ekstrak Etanol Daun Notika (Archboldiodendron calosercium 
(Kobuski)) Terhadap Larva Artemia salina Leach dengan Menggunakan Metode Brine Shrimp Lethality Test (BSLT), Jurnal Pharmauho Vol 4, No 1

(22) Nofianti, T., Devi, W., dan Yulius, P., (2015), Uji Aktivitas Ekstrak Etanol Krop Kubis Putih (Brassica oleracea L.var. capitata) Terhadap Kadar Kolesterol Total Dan Trigliserida Serum Darah Tikus Putih Jantan Galur Wistar, Jurnal Kesehata Bakti Tunas Husada, 14(1)

(23) Prashant, 2011, Phytochemical Screening and Extraction, Internationale Pharmaceutica Sciencia, 1(1):1-9.

(24) Robinson, T., 1995, Kandungan Senyawa Oraganik Tumbuhan Tinggi., ITB. Bandung.

(25) Sahidin, I., 2012, Mengenal Senyawa Alami, Unhalu Press, Kendari.

(26) Umami, S.R., Sarifa, S.H., Rosita, F., dan Ahefman, H., 2016, Uji Penurunan Kolesterol Pada Mencit Putih (Mus Musculus) Secara In-Vivo Menggunakan Ekstrak Metanol Umbi Talas (Colocasia Esculenta L) Sebagai Upaya Pencegahan Cardiovascular Disease, J. Pijar MIPA, 11(2)

(27) Wurdianing, I., SA Nugraheni, Zen, R., 2014, Efek Ekstrak Daun Sirsak (Annona muricata Linn) Terhadap Profil Lipid Tikus Putih Jantan (Rattus Norvegicus), Jurnal Gizi Indonesia, $\mathbf{3}$ (1) 